\title{
Danish Palliative Care Database
}

This article was published in the following Dove Press journal:

Clinical Epidemiology

25 October 2016

Number of times this article has been viewed

\author{
Mogens Groenvold ${ }^{1,2}$ \\ Mathilde Adsersen' \\ Maiken Bang Hansen' \\ 'The Danish Palliative Care Database \\ (DPD) Secretariat, Research Unit, \\ Department of Palliative Medicine, \\ Bispebjerg Hospital, ${ }^{2}$ Department \\ of Public Health, University of \\ Copenhagen, Copenhagen, Denmark
}

Correspondence: Mogens Groenvold The Danish Palliative Care Database (DPD) Secretariat, Research Unit, Department of Palliative Medicine, Bispebjerg Hospital, 20D, Bispebjerg Bakke 23, 2400 Copenhagen NV, Denmark

Tel +45353 I 3524

Fax +45 353। 207

Email mold@sund.ku.dk
Aims: The aim of the Danish Palliative Care Database (DPD) is to monitor, evaluate, and improve the clinical quality of specialized palliative care (SPC) (ie, the activity of hospital-based palliative care teams/departments and hospices) in Denmark.

Study population: The study population is all patients in Denmark referred to and/or in contact with SPC after January 1, 2010.

Main variables: The main variables in DPD are data about referral for patients admitted and not admitted to SPC, type of the first SPC contact, clinical and sociodemographic factors, multidisciplinary conference, and the patient-reported European Organisation for Research and Treatment of Cancer Quality of Life Questionaire-Core-15-Palliative Care questionnaire, assessing health-related quality of life. The data support the estimation of currently five quality of care indicators, ie, the proportions of 1 ) referred and eligible patients who were actually admitted to SPC , 2) patients who waited $<10$ days before admission to SPC, 3) patients who died from cancer and who obtained contact with SPC, 4) patients who were screened with European Organisation for Research and Treatment of Cancer Quality of Life Questionaire-Core-15-Palliative Care at admission to SPC, and 5) patients who were discussed at a multidisciplinary conference.

Descriptive data: In 2014, all 43 SPC units in Denmark reported their data to DPD, and all 9,434 cancer patients (100\%) referred to SPC were registered in DPD. In total, 41,104 unique cancer patients were registered in DPD during the 5 years 2010-2014. Of those registered, $96 \%$ had cancer.

Conclusion: DPD is a national clinical quality database for SPC having clinically relevant variables and high data and patient completeness.

Keywords: specialized palliative care, cancer, quality indicator, patient-reported outcomes, multidisciplinary conference, EORTC QLQ-C15-PAL

\section{Aim for database}

The Danish Board of Health has defined a clinical quality database as:

[...] a register containing quantitative indicators, which are based on the individual patient trajectory and can elucidate the overall quality or parts of the overall quality of the health care system's activity and results for a defined group of patients. ${ }^{1}$

The aim of the Danish Palliative Care Database (DPD) is to monitor, evaluate, and improve the clinical quality of specialized palliative care (SPC) (ie, the activity of hospital-based palliative care teams/departments and hospices) in Denmark. ${ }^{2}$

\section{Study population}

The study population for DPD is all patients in Denmark who 
- have been referred to SPC and/or

- have been admitted to SPC.

Patients who have been referred to or have been admitted to SPC prior to the opening of DPD (January 1, 2010) are not part of the study population and are not included in the database.

The reason for including referred patients who have not been admitted to SPC is that access to SPC was judged to be an important aspect of quality: at the time when the DPD was designed, it was often reported in media that particularly the hospices had to decline access due to insufficient capacity.

"Being admitted to SPC" requires the initiation of palliative care, ie, at least one consultation between the patient and the SPC unit in any location (the patient's home, the SPC unit, a non-SPC hospital department, etc). A patient who has only had contact with the SPC unit via telephone or who has only been evaluated with regard to eligibility is not regarded as having been admitted to SPC.

Each patient is registered once in DPD by each SPC unit receiving a referral of or admitting the patient. Thus, a patient having had contact with more than one SPC unit will appear with one registration for each of these SPC units. The same is the case for a patient who has been referred to more than one SPC unit but was not admitted to any of these units.

Between 2010 and 2014, 41,104 cancer patients were registered in DPD (2010: 6,041; 2011: 7,904; 2012: 8,743; 2013: 8,982; and 2014: 9,434). In addition, patients with other diagnoses such as respiratory, cardiovascular, and neurological diseases (in 2014: 4\% of all patients) are registered.

According to the rules for clinical quality databases approved by the Danish Board of Health, registration of patients in DPD is mandatory for the SPC units.

\section{Main variables}

Table 1 lists all variables and their categories and indicates the variables that are used to estimate the following five quality indicators:

1. Proportion of referred, relevant patients who were actually received in SPC.

2. Proportion of patients who waited $<10$ days before admission to SPC.

3. Proportion of patients who died from cancer and who obtained contact with a SPC.

4. Proportion of patients screened with European Organisation for Research and Treatment of Cancer Quality of Life Questionaire-Core-15-Palliative Care (EORTC QLQ-C15$\mathrm{PAL})^{3}$ questionnaire at admission to SPC.

5. Proportion of patients discussed at a multidisciplinary conference.
In addition to the variables needed for the quality indicators, the DPD includes clinical and sociodemographic variables and patient-reported outcomes at baseline (EORTC QLQ-C15-PAL scores). The first two quality indicators focus on access and waiting time. Problems related to these issues were often publicly debated before the creation of the DPD, and there was no national data available. The third indicator is a bit untypical by being a measure of access at the regional level. When developing the DPD, there was no knowledge as to whether the proportion of cancer patients who were admitted to SPC was similar in different parts of the country or whether this proportion corresponded to figures in other countries. This indicator will be subdivided into different types of contact (inpatient, out-patient, home visit, and consultation at non-SPC hospital department) when linking with the Danish National Patient Register has been established (work in progress).

There is evidence that not all the patients' symptoms and problems are detected if a systematic assessment is not conducted. ${ }^{4-6}$ This motivates the fourth quality indicator, which requests that the patient has completed the EORTCQLQ-C15-PAL questionnaire at the day of first contact with SPC or up to 3 days before. The EORTC QLQ-C15-PAL ${ }^{3}$ is an abbreviated version of the internationally most widely used instrument assessing healthrelated quality of life in cancer patients, the EORTC QLQ-C30, which was developed by the European Organization for Research and Treatment of Cancer. ${ }^{7,8}$ To develop an instrument with minimal patient burden while preserving the advantages of (and comparability with) a well-validated instrument used in thousands of studies, the QLQ-C15-PAL was established by reducing the QLQ-C30 from 30 to 15 items by shortening scales and by deleting the items that were not important for patients in palliative care. $^{3}$ The content of the ten scales is shown in Table 1.

Patient-reported outcomes may be very important variables in clinical databases, and data from the EORTC QLQ-C15-PAL can be used to describe the baseline levels of symptoms and problems in the patients admitted to SPC and for other purposes.

SPC is defined as a multiprofessional and interdisciplinary approach. ${ }^{9}$ Therefore, the fifth quality indicators measures whether it is documented in the medical record that the patient has been discussed at a multidisciplinary conference with representation from at least four disciplines (medical secretaries not included) present.

Most of the variables in DPD are entered by the SPC units in a web-based data entry system called Clinical Measurement System (in Danish: Klinisk Målesystem [KMS]). The following two paper-based forms are used for this: a data form consisting of 18 items and the patient-completed questionnaire 
Table I Variables in the Danish Palliative Care Database (DPD): variable name, categories, purpose, data completeness, and data quality

\begin{tabular}{|c|c|c|c|c|}
\hline Variable name & Categories & $\begin{array}{l}\text { Purpose and } \\
\text { relation to } \\
\text { indicators }\end{array}$ & $\begin{array}{l}\text { Data } \\
\text { completeness } \\
(20 \mid 4), \%\end{array}$ & Data quality \\
\hline \multicolumn{5}{|c|}{ Variables available for all patients registered in DPD } \\
\hline $\begin{array}{l}\text { Central Person } \\
\text { Registration (CPR) } \\
\text { number }\end{array}$ & $\begin{array}{l}\text { A unique ten digit number } \\
\text { including date of birth and } \\
\text { sex }\end{array}$ & \multicolumn{2}{|c|}{ Link to other registers I00 } & $\begin{array}{l}\text { A unique identification number used in all } \\
\text { contacts to public authorities, etc }\end{array}$ \\
\hline Date of birth & Date & Descriptive & 100 & Extracted from CPR number \\
\hline Sex & $\begin{array}{l}\text { Male } \\
\text { Female }\end{array}$ & Descriptive & 100 & Extracted from CPR number \\
\hline Referral date & Date & Used for indicator I & 100 & $\begin{array}{l}\text { Referral dates before January I, } 2010 \text { (which } \\
\text { leads to exclusion), or after registration date } \\
\text { are flagged and checked }\end{array}$ \\
\hline Age at referral & $\begin{array}{l}\text { Years (estimated from date } \\
\text { of birth and referral date) }\end{array}$ & & 100 & \\
\hline $\begin{array}{l}\text { Referral unit } \\
\text { (who referred } \\
\text { the patient to SPC) }\end{array}$ & $\begin{array}{l}\text { General practitioner } \\
\text { Medical specialist } \\
\text { (not working in hospital) } \\
\text { Hospital department } \\
\text { Another SPC unit } \\
\text { The patient or carer } \\
\text { Other }\end{array}$ & Descriptive & 100 & \\
\hline Diagnosis & $\begin{array}{l}\text { Cancer diagnosis } \\
\text { (if applicable) } \\
\text { using ICD-I0 } \\
\text { Noncancer diagnosis } \\
\text { Cardiovascular disease } \\
\text { (100-I28, I30-I5I, I60-199) } \\
\text { Neurological disease } \\
\text { (G00-3I, G35-H95) } \\
\text { AIDS (B20-24) } \\
\text { Other disease }\end{array}$ & Descriptive & 100 & $\begin{array}{l}\text { Validity has been evaluated; manuscript } \\
\text { unpublished }\end{array}$ \\
\hline SPC started & $\begin{array}{l}\text { Yes } \\
\text { No }\end{array}$ & $\begin{array}{l}\text { Used for indicators } \\
\mathrm{I}-5\end{array}$ & 100 & $\begin{array}{l}\text { Checked by linking with Danish National } \\
\text { Patient Register. Any persons registered with } \\
\text { SPC contact but not in DPD are flagged and } \\
\text { checked }\end{array}$ \\
\hline Variables available & for patients not admitted to & SPC & & \\
\hline $\begin{array}{l}\text { Referral criteria } \\
\text { fulfilled? }\end{array}$ & $\begin{array}{l}\text { Yes } \\
\text { No } \\
\text { Cannot be determined }\end{array}$ & Used for indicator I & 89 & \\
\hline $\begin{array}{l}\text { If referral criteria } \\
\text { were fulfilled, } \\
\text { why not SPC? }\end{array}$ & $\begin{array}{l}\text { Unsuitable for treatment. Why? } \\
\text { Refused SPC } \\
\text { Died before SPC } \\
\text { Lack of capacity in SPC unit } \\
\text { Admitted by another SPC unit } \\
\text { Other reason }\end{array}$ & Used for indicator I & 100 & \\
\hline $\begin{array}{l}\text { Reason for not being } \\
\text { suitable for treatment }\end{array}$ & Open ended & & & \\
\hline $\begin{array}{l}\text { If referral criteria } \\
\text { were not fulfilled, } \\
\text { which criteria were } \\
\text { not fulfilled? }\end{array}$ & $\begin{array}{l}\text { Not cancer } \\
\text { Not incurable disease } \\
\text { Not symptoms that } \\
\text { required specialized or } \\
\text { multidisciplinary assistance } \\
\text { Diagnostic process not } \\
\text { completed } \\
\text { The patient was not } \\
\text { informed about the disease } \\
\text { Other }\end{array}$ & Descriptive & 100 & \\
\hline
\end{tabular}


Table I (Continued)

\begin{tabular}{|c|c|c|c|c|}
\hline Variable name & Categories & $\begin{array}{l}\text { Purpose and } \\
\text { relation to } \\
\text { indicators }\end{array}$ & $\begin{array}{l}\text { Data } \\
\text { completeness } \\
(20 \mid 4), \% \\
\end{array}$ & Data quality \\
\hline \multicolumn{5}{|c|}{ Variables available only for patients admitted to SPC } \\
\hline $\begin{array}{l}\text { Date of first SPC } \\
\text { contact }\end{array}$ & $\begin{array}{l}\text { Date } \\
\text { The date is specified } \\
\text { as the first (physical) } \\
\text { contact where treatment } \\
\text { is considered, thus any } \\
\text { prior contact to determine } \\
\text { eligibility or telephone } \\
\text { contacts are not included }\end{array}$ & $\begin{array}{l}\text { Used for indicators } \\
\mathrm{I}, 4 \text {, and } 5\end{array}$ & 100 & $\begin{array}{l}\text { Checked by linking with Danish National } \\
\text { Patient Register. Any persons registered with } \\
\text { SPC contact but not in DPD are flagged and } \\
\text { checked }\end{array}$ \\
\hline Type of first contact & $\begin{array}{l}\text { Outpatient } \\
\text { Inpatient }\end{array}$ & Descriptive & 100 & \\
\hline $\begin{array}{l}\text { Place of first contact } \\
\text { (to be completed } \\
\text { if type of first contact } \\
\text { was outpatient) }\end{array}$ & $\begin{array}{l}\text { SPC outpatient clinic } \\
\text { Home visit } \\
\text { SPC consultation in } \\
\text { a non-SPC unit }\end{array}$ & Descriptive & 100 & \\
\hline $\begin{array}{l}\text { Status at completion } \\
\text { of contact }\end{array}$ & $\begin{array}{l}\text { Dead } \\
\text { Alive }\end{array}$ & Descriptive & & \\
\hline $\begin{array}{l}\text { Place of death (to be } \\
\text { completed if the } \\
\text { patient had been in } \\
\text { contact with the } \\
\text { SPC unit until } \\
\text { death) }\end{array}$ & $\begin{array}{l}\text { At home } \\
\text { In this SPC unit } \\
\text { In another SPC unit } \\
\text { Non-SPC hospital department } \\
\text { Respite care } \\
\text { Other place/unknown }\end{array}$ & Descriptive & 100 & \\
\hline Children & $\begin{array}{l}\text { No children } \\
\text { Children, at least } \\
\text { one younger than } 18 \text { years } \\
\text { Children, all at least } \\
\text { I8-years-old } \\
\text { Unknown }\end{array}$ & Descriptive & 93 & \\
\hline Residence & $\begin{array}{l}\text { Private residence } \\
\text { (flat, house, etc) } \\
\text { Nursing home/ } \\
\text { senior residence } \\
\text { Other } \\
\text { Unknown }\end{array}$ & Descriptive & 96 & \\
\hline $\begin{array}{l}\text { Cohabitation } \\
\text { status }\end{array}$ & $\begin{array}{l}\text { Living alone } \\
\text { Living with spouse/partner } \\
\text { Living with children } \\
\text { Living with spouse/partner } \\
\text { and children } \\
\text { Living with parent(s) } \\
\text { Living with others } \\
\text { Unknown }\end{array}$ & Descriptive & 99 & \\
\hline $\begin{array}{l}\text { Has the patient been } \\
\text { discussed at a } \\
\text { multidisciplinary } \\
\text { conference in the } \\
\text { SPC unit? }\end{array}$ & $\begin{array}{l}\text { Yes, with four or more } \\
\text { professions present and } \\
\text { specified and a written } \\
\text { conclusion in the medical } \\
\text { record } \\
\text { Yes, with two or three } \\
\text { professions present and } \\
\text { specified and a written } \\
\text { conclusion in the medical } \\
\text { record } \\
\text { Not documented in the } \\
\text { record }\end{array}$ & Used for indicator 5 & 100 & \\
\hline
\end{tabular}


Table I (Continued)

\begin{tabular}{|c|c|c|c|c|}
\hline Variable name & Categories & $\begin{array}{l}\text { Purpose and } \\
\text { relation to } \\
\text { indicators }\end{array}$ & $\begin{array}{l}\text { Data } \\
\text { completeness } \\
(20 \mid 4), \% \\
\end{array}$ & Data quality \\
\hline $\begin{array}{l}\text { Date of } \\
\text { multidisciplinary } \\
\text { conference }\end{array}$ & Date & Used for indicator 5 & 100 & \\
\hline $\begin{array}{l}\text { Patient completion of } \\
\text { EORTC QLQ-CI5-PAL } \\
\text { questionnaire }\end{array}$ & $\begin{array}{l}\text { Yes } \\
\text { No - too ill } \\
\text { No - refused } \\
\text { No - not explained }\end{array}$ & Used for indicator 4 & 100 & \\
\hline EORTC QLQ-CI5-PAL & $\begin{array}{l}\text { Responses to the } 15 \text { items } \\
\text { (raw data) and estimated } \\
\text { scores for } 10 \text { scales: } \\
\text { Physical function, } \\
\text { emotional function, pain, } \\
\text { fatigue, nausea/vomiting, } \\
\text { dyspnea, lack of appetite, } \\
\text { constipation, sleeping } \\
\text { difficulties, overall quality } \\
\text { of life }\end{array}$ & & & \\
\hline Date of death & Date & $\begin{array}{l}\text { Used for all indicators } \\
\mathrm{I}-5\end{array}$ & & $\begin{array}{l}\text { Obtained by linking with the Danish Civil } \\
\text { Registration System }\end{array}$ \\
\hline
\end{tabular}

Abbreviations: SPC, specialized palliative care; ICD-10, International Statistical Classification of Diseases and Related Health Problems Tenth Revision.

EORTC QLQ-C15-PAL. ${ }^{3}$ The information for completion of the data form is extracted from the medical record, including documents relating to referral. This typically takes place after the patient's death or after contact has been stopped. The variables in DPD have a high level of data completeness, with completeness $\sim 100 \%$ for several variables, reflecting that these fields are mandatory in the reporting (Table 1).

\section{Follow-up}

As all data for each patient are entered at a single point of time, there is no subsequent follow-up.

The DPD Board is planning two expansions of the DPD related to follow-up. First, detailed data about all SPC activity subsequent to the first contact will be added to the DPD via linking with the Danish National Patient Register (using the unique personal registration number), which contains all hospital and hospice contacts.

Second, it is planned to add a second assessment with the EORTC QLQ-C15-PAL questionnaire, ${ }^{3}$ in addition to the first, which is completed by the patient at the first contact. The second assessment will take place $\sim 1-4$ weeks later and will allow evaluation of change in each of the scores after initiation of SPC, ie, "response to treatment."

\section{Examples of research}

Two ongoing $\mathrm{PhD}$ projects are based on $\mathrm{DPD}$ data and take place in the DPD Secretariat at Bispebjerg Hospital (Table 2).
In the first, data from DPD are linked with other national registers in Denmark, the Danish Register of Causes of Death, ${ }^{10}$ the Danish Civil Registration System, ${ }^{11}$ the Danish Cancer Registry, ${ }^{12}$ and Statistics Denmark to investigate social inequality in admittance to SPC. In the second project, the data from the EORTC QLQ-C15-PAL are analyzed in order to better understand the epidemiology of symptoms and problems in the patients admitted to SPC.

Table 2 Examples of research with data from the Danish Palliative Care Database (DPD)

\begin{tabular}{|c|c|}
\hline $\begin{array}{l}\text { Name of the } \\
\text { researcher }\end{array}$ & Title \\
\hline \multicolumn{2}{|c|}{ Projects based on the DPD } \\
\hline $\begin{array}{l}\text { M Adsersen } \\
\text { (PhD project) }\end{array}$ & $\begin{array}{l}\text { Inequality in admittance to Specialized } \\
\text { palliative care (SPC) in Danish patients with } \\
\text { cancer }\end{array}$ \\
\hline $\begin{array}{l}\text { MB Hansen } \\
\text { (PhD project) }\end{array}$ & $\begin{array}{l}\text { Symptoms and problems in patients with } \\
\text { cancer in specialized palliative care (SPC) }\end{array}$ \\
\hline \multicolumn{2}{|c|}{ Projects using data from DPD } \\
\hline C Bell & $\begin{array}{l}\text { Survival time after diagnosis of terminal } \\
\text { illness: a Nationwide Danish Cohort Study }\end{array}$ \\
\hline KS Benthien & The impact of specialist Palliative Care on \\
\hline (PhD project) & $\begin{array}{l}\text { Medical Treatment and Place of Care for } \\
\text { Patients with Cancer }\end{array}$ \\
\hline AT Johnsen & The Danish Palliative Care Trial (DanPaCT) \\
\hline LR Nylandsted & $\begin{array}{l}\text { Use of the VOICES-SF among bereaved } \\
\text { carers in Denmark: validation and cultural } \\
\text { adaptation }\end{array}$ \\
\hline $\begin{array}{l}\text { AK Winthereik } \\
\text { (PhD project) }\end{array}$ & General practitioners and end-of-life care \\
\hline
\end{tabular}


Data from the DPD play an important role in several other projects (Table 2).

\section{Administrative issues and funding}

The DPD Secretariat supports the 43 SPC institutions, which report data to DPD, at a daily basis concerning questions and problems in relation to the mandatory entering of data in DPD, and carries out analyses of and validation of data. Data from DPD are continuously validated against the Danish National Patient Register to ensure that all patients are entered in DPD: it is checked whether all patients registered in the Danish National Patient Register as having a contact with an SPC unit are registered in DPD, and whether there is agreement about the date of admission. To clarify any discrepancies, the DPD Secretariat contacts the SPC units if there is disagreement between the two data sources. Any errors detected are corrected. This ensures a high completeness of patients in the database: in 2014, the patient completeness was $100 \%$, ie, all patients registered with an SPC contact in the Danish National Patient Register were also registered in the DPD. The DPD Secretariat, in collaboration with the DPD Board, produces an Annual Report in Danish showing the results of the indicators overall and at the SPC unit level and at the regional level. ${ }^{2}$

The SPC institutions have access to their own data, and the DPD Secretariat offers courses in handling and analyzing their own data.

DPD is funded by the Danish Regions (who are the owners and administrators of the public hospitals) via The Danish Clinical Registries (RKKP).

\section{Conclusion}

Prior to the establishment of DPD, there was no knowledge about the quantity or quality of SPC at the national level. The past years of work with the DPD have shown that it is possible to establish a national clinical quality database with a high level of completeness even in a newly established, very busy, and very heterogeneous part of the health care system. This positive development probably reflects the perceived importance of the data produced by the DPD (both about quantity and quality), the high level of professional motivation in the SPC units and the DPD Board, the relatively modest registration burden, the availability of support from a dedicated Secretariat, and the fact that registration in the clinical databases, which are officially approved by the Danish Board of Health, is mandatory.

\section{Acknowledgments}

This paper was funded by the Program for Clinical Research Infrastructure (PROCRIN) established by the Lundbeck
Foundation and the Novo Nordisk Foundation and administered by the Danish Regions. We thank all SPC institutions in Denmark for their contribution and collaboration. Further, we thank the DPD Board, representing the five regions in Denmark, for their work in the development of DPD and the continuing work to improve the database with clinically relevant data. The current members of the DPD Board are Lise Pedersen, Thomas Feveile, Helle Tingrupp, Per Sjøgren, Thor Schmidt, Mogens Grønvold, Bettina Kotasek, Lars Michael Clausen, Anne Marie Olsen, Mette Asbjørn Neergaard, Dorit Simonsen, Helle Bjørn Larsen, and Anette Agerbæk.

\section{Disclosure}

Mogens Groenvold is chairman of the DPD Board and Mathilde Adsersen and Maiken Bang Hansen, PhD students, work part time in the DPD Secretariat. The authors report no other conflicts of interest in this work.

\section{References}

1. National Board of Health (Sundhedsstyrelsen). [Clinical Quality Databases]. Copenhagen: National Board of Health (Sundhedsstyrelsen); 2001:1-40. [In Danish].

2. Hansen MB, Adsersen M, Groenvold M. [Danish Palliative Care Database. Annual Report 2014]. Copenhagen: DMCG-PAL; 2015. [In Danish].

3. Groenvold M, Petersen MA, Aaronson NK, et al. The development of the EORTC QLQ-C15-PAL: a shortened questionnaire for cancer patients in palliative care. Eur J Cancer. 2006;42:55-64.

4. Stromgren AS, Groenvold M, Pedersen L, Olsen AK, Spile M, Sjogren P. Does the medical record cover the symptoms experienced by cancer patients receiving palliative care? A comparison of the record and patient self-rating. J Pain Symptom Manage. 2001;21:189-196.

5. Stromgren AS, Groenvold M, Sorensen A, Andersen L. Symptom recognition in advanced cancer. A comparison of nursing records against patient self-rating. Acta Anaesthesiol Scand. 2001;54:1080-1085.

6. Homsi J, Walsh D, Rivera N, et al. Symptom evaluation in palliative medicine: patient report vs systematic assessment. Support Care Cancer. 2006; 14:444-453.

7. Aaronson NK, Ahmedzai S, Bergman B, et al. The European Organization for Research and Treatment of Cancer QLQ-C30: a quality-of-life instrument for use in international clinical trials in oncology. $J$ Natl Cancer Inst. 1993;85:365-376.

8. Fayers PM, Aaronson N, Bjordal K, et al. The EORTC QLQ-C30 Scoring Manual. 3rd ed. Brussels: European Organization for Research and Treatment of Cancer; 2001.

9. Radbruch L, Payne S. White paper on standards and norms for hospice and palliative care in Europe: part 1. Recommendations from the European Association for Palliative Care. Eur J Palliat Care. 2009;16:278-289.

10. Helweg-Larsen K. The Danish Register of Causes of Death. Scand J Public Health. 2011;39:26-29.

11. Pedersen CB. The Danish Civil Registration System. Scand J Public Health. 2011;39:22-25.

12. Gjerstorff ML. The Danish Cancer Registry. Scand J Public Health. 2011;39:42-45. 


\section{Publish your work in this journal}

Clinical Epidemiology is an international, peer-reviewed, open access, online journal focusing on disease and drug epidemiology, identification of risk factors and screening procedures to develop optimal preventative initiatives and programs. Specific topics include: diagnosis, prognosis, treatment, screening, prevention, risk factor modification,

Submit your manuscript here: http://www.dovepress.com/clinical-epidemiology-journal

\section{Dovepress}

systematic reviews, risk \& safety of medical interventions, epidemiology \& biostatistical methods, and evaluation of guidelines, translational medicine, health policies \& economic evaluations. The manuscript management system is completely online and includes a very quick and fair peer-review system, which is all easy to use. 